Indonesian Journal of Cardiology

Indonesian J Cardiol 20 I 7:38: $160-7$

pISSN: 0I 26-3773 / elSSN: 2620-4762

\title{
Hemodynamic Profiles as a Predictor of Mortality and Length Of Stay in ICCU: Insight from Registry of Acute and Intensive Cardiovascular Care Outcome
}

\author{
Isman Firdaus', Gracia Lilihata², Ardeno Kristianto², Cindya K. Simanjuntak², Siska S. \\ Danny? , Irmalita', Surya Dharma', Dafsah A. Juzar', Daniel P.L. Tobing ${ }^{1}$
}

\footnotetext{
'National

Cardiovascular Center

Harapan Kita, Jakarta,

Indonesia - Department

of Cardiology and

Vascular Medicine,

Universitas Indonesia

2Faculty of Medicine,

Universitas Indonesia,

Jakarta, Indonesia
}

\begin{abstract}
Aims: The ability to differentiate high risk and low risk patients in ICCU is beneficial. Hemodynamic profiles can be used to describe patient's condition immediately. Based on the presence of congestion and poor perfusion, patients can be divided into four hemodynamic profiles. We aim to evaluate the prognostic value of hemodynamic profiles for patient's mortality and length of stay (LOS) in intensive cardiac care unit (ICCU). Methods: In this retrospective cohort study, patients who admitted to ICCU of National Cardiovascular Center Harapan Kita Jakarta, Indonesia, were classified into four hemodynamic profiles: dry-warm, dry-cold, wet-warm, and wet-cold. Bivariate analysis was performed to see the significance between hemodinamic profiles with mortality and LOS, continued with multvariate analysis to evaluate the contribution of other significant factors.

Results: Of 742 patients included, the mortality rate was $7.8 \%$. With dry-warm profile as reference, relative risk for mortality was $2.3(95 \% \mathrm{Cl}$ I.303-4.076), $5.8(95 \% \mathrm{Cl}$ I.992-16.906), and 8.7 (95\% Cl 3.5 I3-2I.567) for wet-warm, dry-cold and wet cold, consecutively. Mean differences of LOS (days) as follows: wet-warm (I.719; $95 \% \mathrm{Cl}$ I.2I-2.23), dry-cold (3.4 I 8; 95\% Cl I.52-5.32), and wet-cold (4.654; 95\% Cl 2.64-6.67) compared to dry-warm. Hemodynamic profiles, especially wet-cold profile, consistently predicted mortality and longer LOS in ICCU by multivariable analysis.

Conclusion: The presence of "wet" profile double the risk of death, "cold" profile has five fold risk of death, while the presence of both has the highest risk for mortality and longer LOS. Hemodynamic profiles assessment successfully serves as an effective predictor for mortality and longer LOS in ICCU.
\end{abstract}

(Indonesian J Cardiol. 2017;38:160-7)

Keywords: Hemodynamic profiles, intensive cardiac care unit, mortality, length of stay, predictor 


\title{
Profil Hemodinamik sebagai Prediktor Mortalitas dan Lama Rawat Pasien di Intensive Cardiac Care Unit (ICCU): Keluaran dari Registry of Acute and Intensive Cardiovascular Care Outcome
}

\author{
Isman Firdaus' ${ }^{1}$, Gracia Lilihata², Ardeno Kristianto², Cindya K. Simanjuntak², Siska S. \\ Danny', Irmalita', Surya Dharma', Dafsah A. Juzar', Daniel P.L. Tobing'
}

\begin{abstract}
Latar Belakang: Kemampuan untuk membedakan pasien resiko tinggi dan resiko rendah di ICCU sangat penting. Profil hemodinamik dapat digunakan untuk mengenali kondisi pasien secara cepat. Berdasarkan adanya tanda kongesti dan perfusi yang buruk pasien dapat dikelompokkan ke dalam empat profil hemodinamik. Studi ini bertujuan untuk mengevaluasi nilai prognostik profil hemodinamik terhadap mortalitas dan lama rawat pasien di Intensive Cardiac Care Unit (ICCU).

Metode : Studi kohort retrospektif ini dilakukan di Rumah Sakit Pusat Jantung dan Pembuluh Darah Nasional Harapan Kita, Jakarta, Indonesia. Pasien yang dirawat di ICCU dikelompokkan ke dalam empat profil hemodinamik: kering-hangat, kering-dingin, basah-hangat dan basah-dingin. Analisis bivariate dilakukan untuk menilai hubungan antara profil hemodinamik dengan mortalitas dan lama rawat di ICCU, dilanjutkan dengan analisis multivariate untuk mengevaluasi kontribusi faktor-faktor lain yang signifikan

Hasil : Total pasien yang ikut dalam studi sebanyak 742 pasien dan tingkat mortalitas sebesar 7,8\%. Resiko relatif (RR) mortalitas untuk profil basah-hangat, kering-dingin dan basah-dingin berturut-turut sebesar 2.3 (95\% CI 1.303-4.076), 5.8 (95\% CI 1.992-16.906), dan 8.7 (95\% CI 3.513-21.567) bila dibandingkan terhadap profil kering-hangat sebagai referensi. Rerata perbedaan lama rawat sebesar 1.719 (95\% CI 1.21-2.23), 3.418 (95\% CI 1.52-5.32), (4.654 (95\% CI 2.64-6.67) untuk profil basah-hangat, kering-dingin, dan basah dingin berturut-turut bila dibandingkan dengan profil kering-hangat. Profil hemodinamik, terutama profil basah-dingin secara konsisten memprediksi mortalitas dan lama rawat yang lebih panjang setelah analisis multivariat.

Kesimpulan: Profil "basah" memiliki resiko mortalitas dua kali lipat, profil "dingin” memiliki resiko mortalitas lima kali lipat, sedangkan keduanya secara bersamaan memiliki resiko mortalitas dan lama rawat lebih panjang paling tinggi. Profil hemodinamik dapat digunakan sebagai prediktor mortalitas dan lama rawat pasien di ICCU secara efektif.
\end{abstract}

(Indonesian J Cardiol. 2017;38:160-7)

Kata Kunci: Profil hemodinamik, intensive cardiac care unit, mortalitas, lama rawat, prediktor

\begin{abstract}
'Departemen Kardiologi dan Vaskular, Fakultas Kedokteran Universitas Indonesia - Rumah Sakit Pusat Jantung dan Pembuluh Darah Nasional Harapan Kita, Jakarta, Indonesia, ${ }^{2}$ Fakultas Kedokteran Universitas Indonesia, Jakarta, Indonesia
\end{abstract}

\section{Correspondence:}

dr. Isman Firdaus, SpJP(K), National Cardiovascular Center Harapan Kita, Jakarta, Indonesia - Department of Cardiology and Vascular Medicine, Universitas Indonesia Jalan Letjen S.Parman Kav. 87, Jakarta Barat II420. Tel.: (+62)8I319990688, Fax.: (+622I) 29424874, E-mail : ismanf@yahoo.com

\section{Latar Belakang}

Intensive cardiac care unit (ICCU) pertama kali dibentuk pada 1960 untuk menyediakan perawatan intensif bagi pasien dengan ST elevation myocardial infarction (STEMI). Namun sejak berkembangnya metode intervensi koroner perkutan primer, pasien 
STEMI kini memiliki prognosis yang lebih baik dan lama rawat di rumah sakit yang lebih pendek. Oleh karena itu, fungsi ICCU kemudian berevolusi untuk merawat lebih banyak pasien dengan penyakit jantung akut yang kompleks, seperti aritmia, gagal jantung akut, dan kondisi hemodinamik yang terganggu. ${ }^{1}$

Pasien di ICCU diklasifikasikan sebagai resiko tinggi dan resiko rendah. Adanya syok kardiogenik, gagal jantung kongestif, aritmia, infark sebelumnya, atau nyeri dada yang menetap menandakan pasien resiko tinggi yang butuh dirawat lebih lama di ICCU. Sebaliknya, pasien resiko rendah dapat dipindahkan dari ICCU dalam 24 jam dan 12-24 jam bebas kejadian yang mengancam. ${ }^{2}$ Kemampuan untuk membedakan kedua kelompok pasien ini penting agar perhatian khusus dapat diberikan pada pasien yang memerlukannya dan pelayanan dapat diberikan secara efisien.

Penilaian profil hemodinamik dapat digunakan sebagai penilaian sederhana tanpa menggunakan prosedur diagnostik yang invasif. Berdasarkan adanya kongesti dan perfusi yang buruk, pasien dibedakan menjadi empat kelompok : kering-hangat, basahhangat, kering-dingin, basah dingin. (Gambar 1)

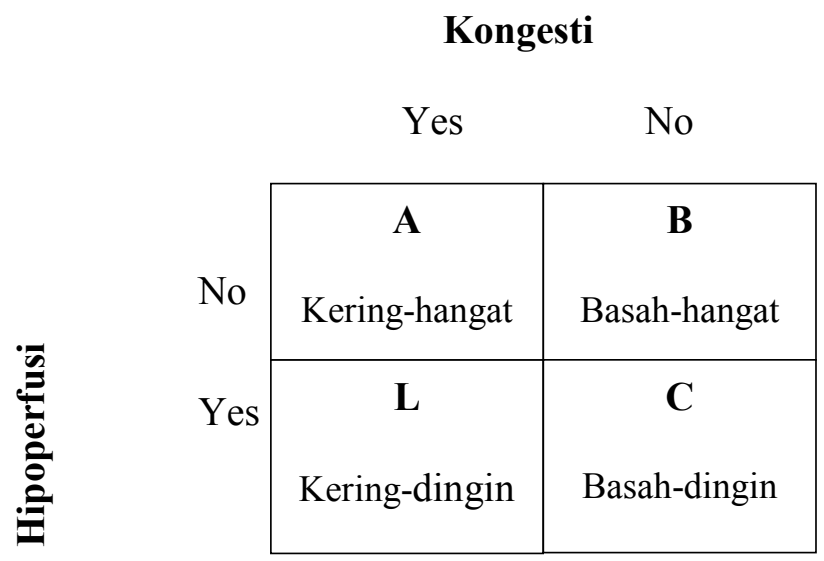

Gambar 1. Gambaran skematik profil hemodinamik

Profil hemodinamik dapat memfasilitasi dokter untuk menangani pasien dengan cepat dan tepat sehingga dapat menurunkan angka mortalitas dan lama rawat. Namun studi mengenai korelasi profil hemodinamik pasien ICCU dengan dengan mortalitas dan lama rawat masih terbatas. Beberapa studi fokus pada penyakit tertentu, seperti pada gagal jantung akut. ${ }^{3-5}$ Studi ini bertujuan untuk mengevaluasi fungsi prognosis profil hemodinamik terhadap mortalitas dan lama rawat pasien di ICCU.

\section{Metode}

Desain studi dan populasi. Ini merupakan sebuah studi kohor retrospektif dengan total 742 pasien yang dirawat di ICCU Rumah Sakit Pusat Jantung dan Pembuluh Darah Nasional Harapan Kita, Jakarta, Indonesia, dari 11 Januari 2011 sampai 12 April 2012. Data dasar pasien dan follow-up selama perawatan di ICCU diperoleh dari registry. Studi ini sesuai dengan prinsip-prinsip yang digariskan dalam Deklarasi Helsinki.

Masuk dan Keluar dari ICCU. Pasien yang dirawat di ICCU memiliki penyakit jantung yang berbahaya, seperti gagal jantung akut, infark miokard atau aritmia maligna, termasuk yang membutuhkan peralatan suportif. Pasien keluar dari ICCU setelah kondisinya stabil (Gambar 2)

Penilaian Profil Hemodinamik. Diagnosis dan profil hemodinamik dinilai oleh tim ICCU yang terdiri dari konsultan kardiolog dan residen. Berdasarkan ada tidaknya tanda kongesti atau perfusi yang inadekuat, profil hemodinamik dibagi menjadi kelompok keringhangat, kering-dingin, basah-hangat, dan basah-dingin. Tanda kongesti merefleksikan profil "basah", termasuk ortopneau, ronki, distensi vena jugular, atau reflux hepatojugular. Tanda perfusi inadekuat merefleksikan profil "dingin", termasuk hipotensi, nadi cepat dan lemah, pulse pressure sempit dan ekstremitas dingin.

Keluaran. Keluaran pertama adalah mengevaluasi hubungan profil hemodinamik dengan mortalitas. Kriteria inklusi adalah semua pasien yang dirawat di ICCU dengan rekam medis yang lengkap termasuk waktu dan penyebab kematian. Pasien yang dirawat di ICCU karena perawatan pasca intervensi, seperti pasca operasi bedah pintas jantung atau intervensi koroner perkuran diekslusi. Didapatkan total 742 pasien untuk analisis mortalitas. Keluaran kedua adalah hubungan profil hemodinamik dengan lama rawat di ICCU. Sebanyak 560 pasien memenuhi kriteria inklusi yaitu rekam medis yang lengkap mengenai tanggal masuk, tanggal keluar dan alasan keluar dari ICCU. Pasien dieksklusi bila meninggal dalam perawatan di ICCU, pulang paksa, atau ditransfer ke rumah sakit yang lain.

Analisis Statistik. Data diolah menggunakan SPSS 19. Data kategorik dipresentasikan dalam angka dan persentase. Sementara data numeric dipresentasikan dalam median dan interquartile range (IQR). Analisis 


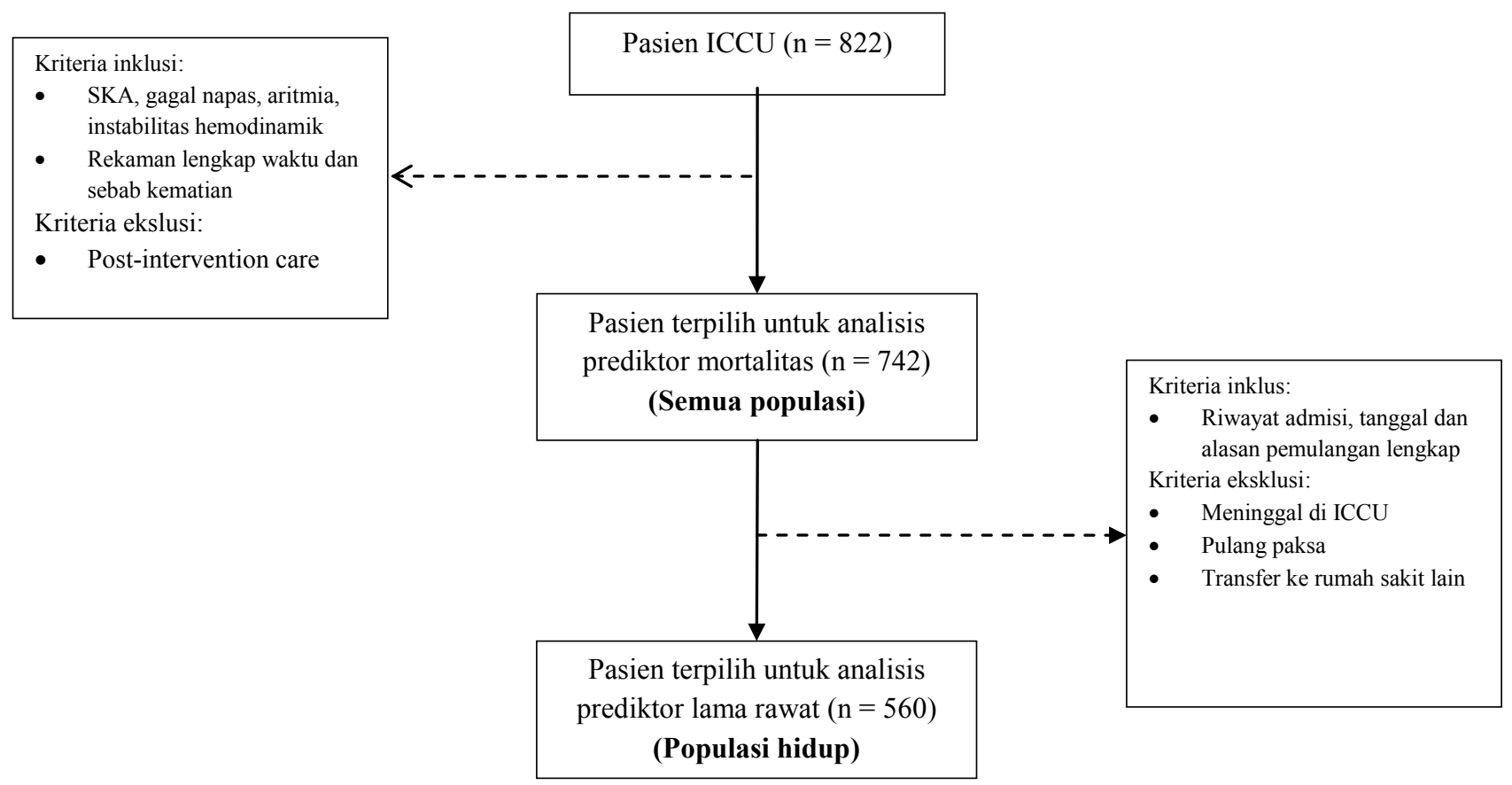

Gambar 2. Algoritma analisis mortalitas dan lama rawat

bivariat dilakukan menggunakan cox regression untuk memperoleh Resiko relatif (RR) mortalitas dari setiap profil hemodinamik dibandingkan kepada profil A (kering-hangat), sedangkan Kruskal-Wallis dilanjutkan dengan analisis post-hoc dilakukan untuk menganalisis rerata perbedaan lama rawat bila data tidak tersebar normal. Analisis multivariate dilakukan dengan menggunakan model cox proportional hazard untuk memperoleh resiko relatif mortalitas dan lama rawat $>3$ hari setelah diadjust terhadap kontribusi faktor-faktor lain.

\section{Hasil}

Karakteristik demografik umum pasien. Dari 742 pasien yang dianalisis, rata-rata umur adalah 58 tahun dan mayoritas adalah laki-laki (80\%) (Tabel 1). Riwayat medis yang dimiliki termasuk hipertensi (33.0\%), dislipidemia (50.7\%), diabetes (38.1\%), dan riwayat keluarga dengan penyakit jantung koroner (23.3\%). Sebanyak 24 pasien $(3.2 \%)$ dirawat ulang di ICCU setelah dipulangkan dalam dua minggu sebelumnya. Diagnosis paling sering adalah Sindrom Koroner Akut (SKA) $(\mathrm{n}=541(73.0 \%))$, gagal jantung akut dekompensata $(n=147(19,8 \%))$, aritmia maligna $(\mathrm{n}=106(14,3 \%))$, edema paru akut $(\mathrm{n}=78(10,5 \%))$, kelainan katup ( $\mathrm{n}=78(10,5 \%))$, syok kardiogenik $(\mathrm{n}=58(7,1 \%))$, dan sebagian kecil kasus adalah kardiomiopati, tamponad dan endokarditis.

Keluaran Mortalitas. Tingkat mortalitas sebesar $7.8 \%$. Dengan profil kering-hangat dijadikan referensi, resiko relatif (RR) untuk profil basah-hangat, keringdingin, dan basah dingin berturut-turut adalah 2.304 (95\% CI 1.303-4.076), 5.803 (95\% CI 1.992-16.906), 8.705 (95\% CI 3.513-21.567). Bivariat juga dilakukan untuk mengevaluasi variabel lain. Prediktor mortalitas yang bermakna $(\mathrm{p}<0.25)$ diikutkan dalam analisis multivariat. (Tabel 2). Setelah Cox regression dengan metode Backward Likelihood Ratio (LR) variabel yang tetap signifikan adalah profil hemodinamik (basahdingin), ureum $>40 \mathrm{mg} / \mathrm{dL}$, hemoglobin $<12 \mathrm{mg} / \mathrm{dL}$ dan gula darah sewaktu $>200 \mathrm{mg} / \mathrm{dL}$. Sindrom koroner akut tetap protektif terhadap mortalitas.

Keluaran Lama Rawat. Lama rawat pasien bervariasi antara 1-24 hari di ICCU dengan median (IQR) 3 (2-4) hari. Rerata perbedaan lama rawat (hari) dengan profil kering-hangat sebagai referensi adalah sebagai berikut : basah-hangat $(1.719$; 95\% CI 1.21 2.23), kering-dingin (3.418; 95\% CI 1.52-5.32) dan basah-dingin (4.654; 95\% CI 2.64-6.67). Lama rawat pasien kemudian dikelompokkan menjadi dua grup: 
Tabel 1. Karakteristik klinis dan demografis pasien

\begin{tabular}{|c|c|c|c|c|c|}
\hline \multirow{2}{*}{ Karakteristik } & \multicolumn{4}{|c|}{ Profil Hemodinamik } & \multirow{2}{*}{$\mathrm{P}^{+}$} \\
\hline & Kering-hangat (457) & Basah-hangat (255) & Kering-dingin (15) & Basah-dingin(15) & \\
\hline Jenis kelamin (laki-laki), $\mathrm{n}(\%)$ & $367(80.3)$ & $200(78.4)$ & $11(73.3)$ & $12(80.0)$ & 1.000 \\
\hline Usia (tahun), median (IQR) & $57(51-66)$ & $60(53-69)$ & $64(61-68)$ & $54(50-62)$ & \\
\hline \multicolumn{6}{|l|}{ Riwayat medis, $\mathrm{n}(\%)$} \\
\hline Merokok & $287(65.5)$ & $147(60)$ & $6(42.9)$ & $6(46.2)$ & 0.364 \\
\hline Hipertensi & $304(66.5)$ & $139(54.7)$ & $11(73.3)$ & $9(60.0)$ & $0.015^{*}$ \\
\hline Dislipidemia & $248(54.6)$ & $117(46.1)$ & $7(46.7)$ & $4(28.6)$ & 0.050 \\
\hline Diabetes & $155(34.1)$ & $114(44.7)$ & $9(60.0)$ & $5(33.3)$ & $0.012^{*}$ \\
\hline Riwayat keluarga PJK & $123(26.9)$ & $47(18.4)$ & $2(13.3)$ & $2(13.3)$ & $0.046^{*}$ \\
\hline Readmisi ke ICCU ${ }^{a}$ & $15(3.3)$ & $9(3.5)$ & $0(0.0)$ & $0(0.0)$ & 1.000 \\
\hline SKA saat admisi, n(\%) & $336(73.5)$ & $189(74.4)$ & $9(60.0)$ & $7(46.7)$ & 0.971 \\
\hline \multicolumn{6}{|c|}{ Pemeriksaan penunjang, median (IQR) } \\
\hline Kreatinin serum $(\mathrm{mg} / \mathrm{dL})$ & $1.1(0.9-1.4)$ & $1.2(1-1.8)$ & $1.6(1.1-3.3)$ & $1.6(1.2-2.5)$ & $0.000^{*}$ \\
\hline Ureum $(\mathrm{mg} / \mathrm{dL})$ & $32(25-42)$ & $38(28-60)$ & $71.5(42.8-111.3)$ & $56(35-126.5)$ & $0.000^{*}$ \\
\hline Hemoglobin (g/dL) & $14.2(12.7-15.3)$ & $13.5(11.7-15)$ & $12.8(10.6-13 . .6)$ & $13.6(10.4-15)$ & $0.000^{*}$ \\
\hline Leukosit $(/ \mu \mathrm{L})$ & $10,950(8740-14,010)$ & $11,360(9080-14,350)$ & $15,895(9428-18,200)$ & $16,080(13,407-21,118)$ & $0.000^{*}$ \\
\hline GDS (mg/dL) & $145(117-195.5)$ & $150(124-222)$ & $132(122.5-233.5)$ & $151.5(117-212)$ & 0.520 \\
\hline Sodium $(\mathrm{mEq} / \mathrm{L})$ & $139(137-141)$ & $138(134-141)$ & $138.5(131.5-141.3)$ & $136.5(133-140)$ & $0.003^{*}$ \\
\hline Potassium $(\mathrm{mEq} / \mathrm{L})$ & $4(3.7-4.4)$ & $4.1(3.7-4.4)$ & $4.2(3.8-4.6)$ & $4.15(3.7-5)$ & 0.809 \\
\hline Ejection fraction $(\%)^{\mathrm{b}}$ & $50(40-60)$ & $38(28.3-50.8)$ & $39(24-59.3)$ & $29(25-42)$ & $0.000^{*}$ \\
\hline
\end{tabular}

${ }^{+}$p value diuji dengan Kruskal-Wallis (numerikal) dan Chi-Square/Kolmogorov-Smirnov (kategorikal)

* berbeda secara signifikan bila $\mathrm{P}<0.05$

${ }^{a}$ dalam dua minggu terakhir

b Saat masuk ICCU

Akronim: IQR: interquartile range; SKA: Sindrom Koroner AKut; PJK: Penyakit Jantung Koroner; ICCU: Intensive Cardiac Care Unit, GDS: Gula darah sewaktu

Tabel 2. Analisis multivariat prediktor mortalitas

\begin{tabular}{|c|c|c|c|}
\hline Faktor resiko mortalitas & $\begin{array}{c}\text { Unadjusted RR } \\
(95 \% \mathrm{CI})\end{array}$ & $\begin{array}{c}\text { Adjusted RR } \\
(95 \% \mathrm{CI})\end{array}$ & Koefisien \\
\hline \multicolumn{4}{|l|}{ Profil hemodinamik } \\
\hline Kering-hangat & Ref & Ref & - \\
\hline Basah-hangat & $2.304(1.303-4.076)$ & $1.481(0.809-2.713)$ & 0.348 \\
\hline Kering-dingin & $5.803(1.992-16.906)$ & $1.996(0.573-6.895)$ & 0.685 \\
\hline Basah-dingin & $8.705(3.513-21.567)$ & $4.162(1.459-11.875)$ & 1.405 \\
\hline Usia> 61 tahun & $1.831(1.088-3.079)$ & $0.998(0.524-1.903)$ & -0.002 \\
\hline Perokok aktif dan mantan perokok & $0.639(0.371-1.101)$ & $0.877(0.480-1.604)$ & -0.131 \\
\hline Diabetes & $1.406(0.840-2.356)$ & $0.786(0.421-1.467)$ & -0.241 \\
\hline Readmisi ke ICCU dalam 2 minggu terakhir & $2.216(0.803-6.119)$ & $1.842(0.544-6.234)$ & 0.611 \\
\hline Ureum $>40 \mathrm{mg} / \mathrm{dL}$ & $3.916(2.205-6.954)$ & $2.518(1.288-4.921)$ & 0.923 \\
\hline Hemoglobin $<12 \mathrm{~g} / \mathrm{dL}$ & $4.024(2.380-6.804)$ & $2.624(1.422-4.843)$ & 0.965 \\
\hline GDS > $200 \mathrm{mg} / \mathrm{dL}$ & $1.741(1.030-2.943)$ & $1.868(1.031-3.386)$ & 0.625 \\
\hline SKA pada admisi & $0.424(0.253-0.711)$ & $0.494(0.274-0.894)$ & -0.704 \\
\hline Kreatinin $>1.2 \mathrm{mg} / \mathrm{dL}$ & $2.085(1.235-3.519)$ & $1.069(0.504-2.267)$ & 0.066 \\
\hline
\end{tabular}

Dicetak tebal: tetap signifikan setelah analisis multivariat

Akronim: SKA: Sindrom Koroner AKut; ICCU: Intensive Cardiac Care Unit, GDS: Gula darah sewaktu 
Firdaus I et al: Hemodynamic Profiles as an Effective Bedside Predictor for in-ICCU Mortality and LOS:

$>3$ hari dan $\leq 3$ hari. Analisis bivariat juga dilakukan untuk variabel lain dan variabel yang signifikan untuk lama rawat $>3$ hari pada analisis bivariat $(\mathrm{p}<0.25)$ diikutkan dalam analisis multivariat. Variabel yang tetap signifikan setelah analisis multivariat adalah profil hemodinamik dan $\mathrm{Hb}<12 \mathrm{~g} / \mathrm{dL}$ (Tabel 3). index (CI). ${ }^{7}$ Bagaimanapun, kateterisasi jantung kanan untuk mengevaluasi PCWP atau CI merupakan pemeriksaan yang sangat invasif sehingga memiliki lebih banyak resiko daripada manfaat bila dilakukan secara rutin. ${ }^{8}$

Dalam studi ini, profil "kering-dingin" memiliki

Table 3. Analisis multivariat untuk lama rawat $>3$ hari

\begin{tabular}{|c|c|c|c|}
\hline Karakteristik & $\begin{array}{c}\text { Unadjusted } R R \\
\text { untuk LOS > } 3 \text { hari } \\
(95 \% \mathrm{CI})\end{array}$ & $\begin{array}{c}\text { Adjusted } R R \\
\text { untuk } \mathrm{LOS}>3 \text { hari } \\
(95 \% \mathrm{CI})\end{array}$ & Koefficien \\
\hline \multicolumn{4}{|l|}{ Profil hemodinamik } \\
\hline Kering-hangat & Ref & Ref & - \\
\hline Basah-hangat & $2.210(1.684-2.900)$ & $2.151(1.621-2.852)$ & 0.766 \\
\hline Kering-dingin & $3.256(1.584-6.694)$ & $3.016(1.459-6.233)$ & 1.104 \\
\hline Basah-dingin & $3.663(1.782-7.531)$ & $3.457(1.600-7.471)$ & 1.241 \\
\hline Usia $>61$ & $1.429(1.097-1.860)$ & $1.214(0.906-1.626)$ & 0.194 \\
\hline Ureum $>40 \mathrm{mg} / \mathrm{dL}$ & $1.714(1.314-2.236)$ & $1.272(0.953-1.697)$ & 0.240 \\
\hline Kreatinin $>1.2 \mathrm{mg} / \mathrm{dL}$ & $1.352(1.038-1.760)$ & $1.037(0.753-1.428)$ & 0.036 \\
\hline Hemoglobin $<12 \mathrm{~g} / \mathrm{dL}$ & $1.683(1.263-2.241)$ & $1.452(1.079-1.953)$ & 0.373 \\
\hline Diabetes & $1.198(1.031-1.392)$ & $1.046(0.792-1.381)$ & 0.045 \\
\hline Riwayat keluarga PJK & $0.871(0.755-1.005)$ & $0.856(0.617-1.187)$ & -0.156 \\
\hline
\end{tabular}

Bold : Remain significant after multivariate analysis

Akronim: PJK: Penyakit Jantung Koroner.

\section{Diskusi}

Tingkat mortalitas di Rumah Sakit Pusat Jantung dan Pembuluh Darah Nasional Harapan Kita dalam periode Januari 2011 - April 2012 adalah 7.8\%. Hasil ini sesuai dengan hasil studi oleh Finkielman et al yang memperoleh tingkat mortalitas sebesar $8.2 \% .^{6}$

Studi ini menemukan bahwa profil hemodinamik adalah prediktor mortalitas dan lama rawat di ICCU yang signifikan untuk beragam pasien di ICCU. Adanya profil "basah" memiliki resiko mortalitas dua kali lipat, sedangkan profil "dingin" memiliki resiko lima kali lipat. "Basah" dan "dingin" sekaligus memiliki resiko mortalitas hingga delapan kali. Untuk lama rawat di ICCU, "basah-hangat" memiliki lama rawat dua hari lebih lama, "kering-dingin" tiga hari lebih lama dan "basah-dingin" empat hari lebih lama.

Nilai prognostik dari profil hemodinamik ini dianggap merupakan hasil dari kemampuannya merefleksikan pemeriksaan yang invasif. Tandatanda kongesti seperti ortopneau dan meningkatnya tekanan vena jugular merefleksikan meningkatnya pulmonary capillary wedge pressure (PCWP), sementara hipoperfusi mengindikasikan menurunnya cardiac prognosis yang lebih buruk dibandingkan "basahhangat" yang menunjukkan bahwa hipoperfusi sendiri memiliki prognosis lebih buruk daripada kongesti. Lebih lanjut, Hansen et al menunjukkan hubungan yang menarik antara perfusi buruk dengan prognosis yang buruk pada pasien. ${ }^{9}$ Mereka memberikan bukti bahwa perfusi yang inadekuat memiliki peran lebih penting pada pola pertukaran gas daripada ventilasi berlebih pada pasien dengan gagal jantung. Oleh karena itu, meskipun pasien dengan gagal jantung memiliki gejala sesak, mereka jarang mengalami gagal napas.

Sementara itu, lama rawat pasien ditentukan oleh terapi yang diterima pasien. Kelompok kontrol, keringhangat, tanpa hipoperfusi atau kongesti, memiliki lama rawat lebih pendek dari kelompok lain. Pada kelompok "basah-hangat" diuretik adalah terapi utama untuk mengurangi tekanan hidrostatik intravaskular dan akumulasi cairan interstitial. Respon tiap individu terhadap diuretik menentukan lama rawat. ${ }^{10,11}$ Pasien dengan profil "kering-dingin" mungkin membutuhkan inotrop atau vasopresor untuk memperbaiki perfusi. Pemberian terapi ini membutuhkan pengaturan dan pemantauan ketat. Terdapat pula efek fisiologis berkepanjangan dari agen- 
agen tersebut yang dapat menyamarkan efek agen-agen lain sehingga pasien harus dirawat hingga 48 jam setelah diskontinuasi agen inotrop.

Konsisten dengan studi-studi lain, profil "basahdingin" memiliki mortalitas tertinggi. ${ }^{6}$ Profil ini dapat dikategorikan sebagai status syok kardiogenik, dengan hipotensi, hipoperfusi dan kongesti ada secara bersamaan. Kelompok ini juga memiliki lama rawat paling panjang di ICCU karena pasien harus bebas dari tanda-tanda hipoperfusi dan kongesti, seperti dispneau atau hipotensi simtomatik sebelum dipindahkan atau dipulangkan. Tanda-tanda objektif, seperti tekanan darah, fungsi ginjal dan status cairan harus stabil dalam minimal 24 jam. ${ }^{12}$

\section{Analisis Multivariat}

Setelah analisis multivariat, profil hemodinamik tetap signifikan terhadap mortalitas (khususnya "basahdingin") dan lama rawat. Ureum $>40 \mathrm{mg} / \mathrm{dL}$ dan kadar gula sewaktu $>200 \mathrm{mg} / \mathrm{dL}$ juga tetap berpengaruh signifikan terhadap mortalitas, sedangkan hemoglobin $<12 \mathrm{~g} / \mathrm{dL}$ signifikan untuk mortalitas dan lama rawat yang lebih panjang di ICCU.

Beberapa studi yang berbeda dari pasien dengan gagal jantung, SKA dan syok kardiogenik menunjukkan bahwa meningkatnya ureum memprediksi tingkat mortalitas yang lebih tinggi pada tiap penyakit jantung yang berbeda, lebih baik daripada kreatinin atau eGFR. ${ }^{12-14}$ Meningkatnya ureum merefleksikan menurunnya perfusi renal yang dapat disebabkan oleh perburukan fungsi jantung, atau sebaliknya, gagal ginjal dapat mengaktivasi respon neurohormonal yang dapat mengganggu fungsi jantung lebih lanjut. Meningkatnya kadar gula sewaktu atau puasa juga diasosiasikan dengan fungsi ventrikel kiri yang lebih buruk dan mortalitas lebih tinggi pada pasien kardiovaskular, terutama yang berhubungan dengan penyakit jantung iskemik. ${ }^{15,16}$

Anemia juga diasosiasikan dengan tingkat mortalitas lebih tinggi dan lama rawat ICCU lebih panjang pada pasien dengan penyakit jantung. ${ }^{17}$ Pasien kardiak lebih rentan terhadap anemia dan mungkin membutuhkan transfusi yang agresif, ${ }^{18}$ namun harus diperhatikan dengan seksama resiko edema pulmonal.

Studi-studi sebelumnya berfokus pada kondisikondisi khusus, seperti gagal jantung atau infark miokard. Sebaliknya, studi ini dilakukan pada semua spectrum pasien di ICCU dan oleh karena itu dapat diaplikasi kepada semua pasien secara umum. Dalam studi ini, diagnosis SKA pada saat dirawat tampak protektif terhadap mortalitas. Namun SKA merupakan diagnosis yang paling sering ditemui di ICCU dan oleh karena itu tenaga medis menjadi lebih terampil dan ahli dalam penanganannya. Lebih lanjut, SKA lebih sering ditemui pada kelompok kering-hangat dengan hemodinamik yang lebih baik. Usia > 61 tahun juga tampak protektif terhadap mortalitas. Perlu diingat bahwa kelompok basah-dingin (dengan resiko mortalitas tinggi) cenderung berusia muda.

\section{Keterbatasan studi}

Studi ini memiliki beberapa keterbatasan, salah satunya adalah kondisi sosial dan ekonomi di Indonesia dimana tidak semua pasien dilindungi oleh asuransi kesehatan. Oleh karena itu, intervensi dan peralatan yang dibutuhkan, serta keputusan untuk tetap dirawat di ICCU dapat dipengaruhi oleh kemampuan finansial pasien ditambah oleh latar belakang sosial dan budaya keluarga. Selain itu, studi ini hanya mengevaluasi kemampuan prognosis jangka pendek dalam masa perawatan di rumah sakit, sementara kemampuan prognosis jangka panjang juga akan dibutuhkan.

\section{Kesimpulan}

Penilaian profil hemodinamik dapat digunakan sebagai prediktor mortalitas dan lama rawat di ICCU. Penilaian ini sederhana, cepat dan dapat menyediakan stratifikasi resiko dini sehingga terapi yang agresif dan terfokus dapat diberikan lebih awal. Hasilnya adalah prognosis yang lebih baik dan pelayanan yang efisien kepada pasien.

\section{Daftar Singkatan}

\author{
ICCU: Intensive Cardiac Care Unit \\ RR: Resiko relatif \\ LOS: Length of stay \\ STEMI ST-Elevation Myocardial Infarction \\ IQR: Interquartile range \\ SKA: Sindrom koroner akut \\ PCWP: Pulmonary capillary wedge pressure \\ CI: Cardiac index \\ eGFR: Estimated glomerular filtration rate \\ Hb: Hemoglobin \\ GDS: Gula darah sewaktu
}


Firdaus I et al: Hemodynamic Profiles as an Effective Bedside Predictor for in-ICCU Mortality and LOS:

\section{Persetujuan Etik/Ethical Approval}

Penelitian ini telah disetujui oleh Komite IRB/Etik Penelitian Rumah Sakit Pusat Jantung dan Pembuluh Darah Harapan Kita, Jakarta, Indonesia

\section{Persetujuan Publikasi/Publication Agreement}

Semua penulis yang tersebut namanya telah menyetujui artikel ini untuk dipublikasikan pada Indonesian Journal of Cardiology bila diterima.

\section{Conflict of Interest}

Tidak ada/ None declared

\section{Sumber dana/Source of Funding}

Tidak ada

\section{Daftar Pustaka}

1. Walker DM, West NEJ, Ray SG. From coronary care unit to acute cardiac care unit: the evolving role of specialist cardiac care. Heart 2012;98:350-352.

2. Antman EM, Anbe DT, Armstrong PW, Bates ER, Green LA, Hand M, Hochman JS, Krumholz HM, Kushner FG, Lamas GA, Mullany CJ, Ornato JP, Pearle DL, Sloan MA, Smith SC Jr, Alpert JS, Anderson JL, Faxon DP, Fuster V, Gibbons RJ, Gregoratos G, Halperin JL, Hiratzka LF, Hunt SA, Jacobs AK. ACC/AHA guidelines for the management of patients with ST-elevation myocardial infarction - executive summary: a report of the American College of Cardiology/American Heart Association task force on practice guidelines. Circulation 2004;110:588-636.

3. Nohria A, Tsang SW, Fang JC, Lewis EF, Jarcho JA, Mudge $\mathrm{GH}$, Stevenson LW. Clinical assessment identifies hemodynamic profiles that predict outcomes in patients admitted with heart failure. JACC 2003;41(10):1797-1804.

4. Forrester JS, Diamond G, Chatterjee K, Swan HJ. Medical therapy of acute myocardial infarction by application of hemodynamic subsets (second of two parts). $N$ Engl J Med 1976;295:1404-1413.

5. Nohria A, Mielniczuk LM, Stevenson LW. Evaluation and Monitoring of Patients with Acute Heart Failure Syndromes. Am J Cardiol 2005; 96:32G-40G.

6. Finkielman JD, Morales J, Peters SG, Keegan MT, Ensminger
SA, Lymp JF, Afessa B. Mortality rate and length of stay of patients admitted to the intensive care unit in july. Crit Care Med 2004;32(5):1161-1165.

7. Drazner MH, Hellkamp AS, Leier CV, Shah MR, Miller LW, Russell SD, Young JB, Califf RM, Nohria A. Value of clinician assessment of hemodynamics in advanced heart failure: the ESCAPE trial. Circ Heart Fail 2008;1:170-177.

8. Connors AF Jr, Speroff T, Dawson NV, Thomas C, Harrell FE Jr, Wagner D, Desbiens N, Goldman L, Wu AW, Califf RM, Fulkerson WJ Jr, Vidaillet H, Broste S, Bellamy P, Lynn J, Knaus WA. The effectiveness of right heart catheterization in the initial care of critically ill patients. SUPPORT Investigators. JAMA 1996; 276(11):889-897.

9. Hansen JE, Sun XG, Stringer WW. A simple new visualization of excercise data disclose pathophysiology and severity of heart failure. J Am Heart Assoc 2012; 1: e00183

10. Nohria A, Lewis E, Stevenson LW. Medical management of advanced heart failure. JAMA 2002; 287(5):628-40.

11. Wright SP. Verouhis D, Gamble G, Swedberg K, Sharpe N, Doughty RN. Factors influencing the length of hospital stay of patients with heart failure. Eur J Heart Fail 2003; 5(2):201209.

12. Rohde LE, Goldraich L, Polanczyk CA, Borges AP, Biolo A, Rabelo E, Beck-Da-Silva L, Clausell N.A simple clinically based predictive rule for heart failure in-hospital mortality. J Cardiol Fail 2006;12(8):587-93

13. Klein L, Massie BM, Leimberger JD, O’Connor CM, Piña IL, Adams KF Jr, Califf RM, Gheorghiade M, OPTIME-CHF Investigators. Cardiorenal syndrome: Prognosis and treatment. Circulation Heart Failure. 2008;1(1):25

14. Saygitov RT, Glezer MG, Semakina SV. Blood urea nitrogen and creatinine levels at admission for mortality risk assessment in patients with acute coronary syndromes. Emerg Med J 2010;27(2):105-109.

15. Aronson D, Hammerman H, Suleiman A, Agmon Y, Beyar R, Markiewicz W, Suleiman M.et al. Fasting Glucose in Acute Myocardial Infarction : Incremental value for long-term mortality and relationship with left ventricular systolic function . Diabetes Care April 2007; 30: 960-966.

16. Wahab NN, Cowden EA, Pearce NJ, Gardner MJ, Merry H, Cox JL; ICONS Investigators. et al. Is blood glucose an independent predictor of mortality in acute myocardial infarction in the thrombolytic era? J Am Coll Cardiol 2002;40(10):1748-1754.

17. Gül R, Öner FA, Yurdakul S, Ergüneyet M. The effect of anemia on mortality in patients with acute coronary syndrome. Nobel Med 2011; 7(3): 78-81.

18. Freudenberger RS and Carson JL. Is there an optimal hemoglobin value in the cardiac intensive care unit? Current Opinion in Critical Care 2003, 9:356-361. 